\title{
Supply Chain Management Practices, Competitive Advantages and Firm Performance: A Case of Small and Medium Enterprises (SMEs) in Vietnam*
}

\author{
Duong Vu Xuan Quynh, Nguyen Hoang Huy \\ International University-Vietnam National University, Ho Chi Minh City, Vietnam
}

\begin{abstract}
The perception of supply chain management (SCM) first appeared in 1982 and the very first papers on SCM were published in the mid 1980s (Houlihan, 1985). However, this term is still fresh in Vietnam, especially the subject of SCM practices and their impacts on firm performance of small and medium enterprises (SMEs). Therefore, the research was conducted to study the impact of supply chain management practices (SCMPs) on firm performance of SMEs through firm competitive advantages. Data were collected by surveying SMEs located in Ho Chi Minh City. The research findings showed that customer relationship (CR) and quality of information sharing (IQ) impact on firm performance at $0.01 \%$ significance level while the level of information sharing impacts on firm performance at $10 \%$ significance level, and strategic supplier partnership impacts on firm performance insignificantly. Moreover, we also found that customer relationship and quality of information sharing influence firm competitive advantage at $0.01 \%$ significance level, while strategic supplier partnership and the quality of information sharing impact on firm competitive advantage at 5\% significance level. Competitive advantages impact significantly positively on firm performance at significance level of $0.001 \%$. The findings imply that SMEs in Vietnam should manage customer relationship well and increase the level of information quality to improve competitive advantage in order to gain high performance.
\end{abstract}

Keywords: SCM practices, competitive advantages, firm performance, SMEs, Vietnam

\section{Introduction}

Since the 1990s, Vietnam has joined in many free trade zones and Free Trade Agreements such as Association of Southeast Asian Nations (ASEAN), Asia Pacific Economic Cooperation (APEC), World Trade Organization (WTO), and Comprehensive and Progressive Agreement for Trans-Pacific Partnership (CPTPP). The key challenge that Vietnam faces is the productivity improvement to sustain its economic growth. Better performing logistics can be a main source of increasing productivity, as well as reducing the product cost of

\footnotetext{
* Acknowledgement: I would like to express my deepest appreciation to International University - Vietnam National University, Office of Research and Development as well as the Journal of Modern Accounting and Auditing which provided me useful supports in this study. I would also like to give a special gratitude to all lecturers in the Department of Industrial and Systems Engineering of International University - Vietnam National University, Mr. Nguyen Hoang Huy, whose contribution is in stimulating suggestions and encouragement, which helped me to coordinate my project especially in writing this paper.

Duong Vu Xuan Quynh, Undergraduate, Department of Industrial and Systems Engineering, International University-Vietnam National University. Email: duongk14iu@gmail.com.

Nguyen Hoang Huy, Full-Time Lecturer, Department of Industrial and Systems Engineering, International University-Vietnam National University.
} 
international and domestic exporters located in Vietnam. Traditional supply chain management (SCM) theories postulate that information, communication, cooperation, and trust are critical to attain the level of synchronization to make it more responsive to customer needs while lowering costs (Russell \& Taylor, 2009). Although there are many researches focusing on the impact of SCM practices on firm performance and competitive advantages conducted in developed and developing countries, there is still a lack of such studies conducted in Vietnam. Therefore, this study aims to test the relationship between SCM practices and firm performance with firm competitive advantage as a mediating variable.

This manuscript consists of five sections. The first section introduces the rationale for study and the study's purposes. The second section presents the literature review on SCM, SCMPs, and the relationship between SCMPs and firm competitive advantages and performance. The third section discusses the research model and hypotheses, and presents measurement scales of latent variables. The fourth section presents the research findings and discussion. The last section is conclusion and limitations of the study.

\section{Literature Review}

\section{Supply Chain Management (SCM)}

Many studies in SCM have been conducted to identify the SCM concept; as a result, many definitions have appeared along with the development in the cognition of this term. For instance, SCM is illustrated as the systemic and strategic coordination of the traditional business functions and the tactics across these business functions within a particular company and across businesses within the supply chain (Dewitt et al., 2001; as cited in Afande, Ratemo, \& Nyaribo, 2015); SCM is also defined as the coordination of production, inventory, location, and transportation among the participants in a supply chain to achieve the best mix of responsiveness and efficiency for the market being served (Wiley, 2009; as cited in Afande et al., 2015); Cooper, Lambert, and Pagh (1997), Lambert and Cooper (2000), and Somuyiwa, Mcilt, and Adebayo (2012) defined SCM as the management of material, money, men and information within and across the supply chain to maximize the customer satisfaction and to enhance the competitive advantage. Although there is no general accepted concept of SCM among researches, all the definitions have one common objective, namely, bringing the benefit for all the members (supplier, intermediaries, third party service providers, and customers) of the supply chain. The evolutionary nature and complexity of SCM are also reflected in the SCM research (Li, Rao, T. S. Ragu-Nathan, \& B. Ragu-Nathan, 2005).

\section{Supply Chain Management Practices (SCMPs)}

SCMPs are defined as the set of activities undertaken by an organization to promote effective management of its supply chain. The practices of SCM are proposed to be a multi-dimensional concept. Many different aspects of SCMPs have been discussed in various studies in the past. Li, B. Ragu-Nathan, T. S. Ragu-Nathan, and Rao (2006) reviewed SCM practice literature and consolidated five distinctive elements of SCMPs including strategic supplier partnership, customer relationship, level of information sharing, quality of information sharing and postponement. According to Afande et al. (2015), these five constructs cover upstream (strategic supplier partnership) and downstream (customer relationship) sides of a supply chain, information flow across a supply chain (level of information sharing and quality of information sharing), and internal supply chain process (postponement). The other detailed descriptions of SCMPs' constructs are summarized in Table 1 below.

Tan (2001) suggested five constructs of SCMPs including supply chain integration, information sharing, supply chain characteristics, customer service management, and geographical proximity and JIT capability. It 
seems that they emphasize more on customer relationship. Other researchers also concentrate on the relationship among suppliers and customers such as Burgess and Singh (2006), Lenny Koh, Demirbag, Bayraktar, Tatoglu, and Zaim (2007), Ellram, Tate, and Billington (2007), and Khang, Arumugam, Chong, and Chan (2010).

Table 1

Summary of SCMPs' Constructs

\begin{tabular}{|c|c|}
\hline Suggested by author(s) & SCMPs' constructs \\
\hline Chen and Paulraj (2004) & \begin{tabular}{|l|} 
Supplier base reduction \\
Long-term relationship \\
Communication \\
Cross-functional teams \\
Supplier involvement \\
\end{tabular} \\
\hline Min and Mentzer (2004) & $\begin{array}{l}\text { Agreed vision and goals } \\
\text { Information sharing } \\
\text { Risk and award sharing } \\
\text { Cooperation } \\
\text { Process integration } \\
\text { Long-term relationship } \\
\text { Agreed supply chain leadership }\end{array}$ \\
\hline Li et al. (2005) & $\begin{array}{l}\text { Strategic supplier partnership } \\
\text { Customer relationship } \\
\text { Information sharing } \\
\text { Internal lean practices } \\
\text { Postponement }\end{array}$ \\
\hline Burgess and Singh (2006) & \begin{tabular}{|l} 
Leadership \\
Intra-organizational relationships \\
Inter-organizational relationships \\
Logistics \\
Process improvement orientation \\
Information systems \\
Business results and outcomes \\
\end{tabular} \\
\hline Lenny Koh et al. (2007) & \begin{tabular}{|l|} 
Just in time supply \\
Many suppliers \\
Holding safety stock \\
Subcontracting \\
Few suppliers \\
Close partnership with suppliers \\
Strategic planning \\
Outsourcing \\
Third party logistics (3PL) \\
Close partnership with customers \\
E-procurement \\
Supply chain benchmarking
\end{tabular} \\
\hline Ellram et al. (2007) & $\begin{array}{l}\text { Information flow } \\
\text { Capacity and skills management } \\
\text { Demand management } \\
\text { Customer relationship management } \\
\text { Supplier relationship management } \\
\text { Service delivery management } \\
\text { Cash flow }\end{array}$ \\
\hline Khang et al. (2010) & $\begin{array}{l}\text { Demand management } \\
\text { Customer relationship management } \\
\text { Supplier relationship management } \\
\text { Capacity and resource management } \\
\text { Service performance } \\
\text { Information and technology management } \\
\text { Service supply chain finance } \\
\text { Order process management }\end{array}$ \\
\hline
\end{tabular}




\section{Supply Chain Practices and Organizational Performances}

A number of studies have been conducted to determine whether SCMPs have a positive impact on firm performance (Zailani, Jeyaraman, Vengadasan, \& Premkumar, 2012). Söderberg and Bengtsson (2010) concluded that if firms use maturity indicators in Supply Chain Operations Reference areas to improve their processes, they will most likely achieve positive effects on supply chain performance and probably also in financial performance. Lii and Kuo (2016), by focusing on the Taiwan's manufacturing firms, concluded that supply chain integration (in particular, supplier integration and internal integration) has a mediation effect on innovation orientation and business performance. Kim's (2009) researches in the Korean and Japanese firms also indicate that efficient supply chain integration may play a more critical role for sustainable SCM competitiveness in case of Korean firms, while in Japanese firms, the close interrelationship between the level of SCM practices and competition capability may have a more significant impact on SCM competitiveness.

\section{Supply Chain Practices and Competitive Advantage}

$\mathrm{Li}$ et al. (2006) defined competitive advantage as the extent to which an organization is able to create a defensible position over its competitors, comprising capabilities that allow an organization to differentiate itself from its competitors and is an outcome of critical management decisions. They suggested five constructs of competitive advantage which are price/cost, product quality, delivery dependability, production innovation, and time to market.

Followed by the increasing competitivity among supply chains in the global market, organizations tend to find out the way in order to sustain their competitive advantages compared to others. According to Elgazzar, Tipi, Hubbard, and Leach (2012), linking supply chain processes' performance to the company's financial strategic objective enables companies to gain competitive advantages and formulate strategies for improved SCM through linking such strategies to the focus area of enhancing the financial performance.

\section{Strategic Supplier Partnership (SSP) and Firm Performance}

SSP is defined as the long-term relationship between an organization and its suppliers ( $\mathrm{Li}$ et al., 2006). "Partnership" as "an on-going collaborative relationship between two legally separate organizations, based upon a commitment to the equal sharing of the costs, risks and rewards derived from working together" (Chicksand, 2015, p. 3). Sharing benefit is the core factor of partnership. Strategic partnerships with suppliers increase the efficiency or productivity since they are willing to share the success of the products ( $\mathrm{Li}$ et al., 2005). The very common and classic example of sustainable partnership is the family business Procter and Gamble/Wal-Mart relationship - a sustained, successful retail-vendor relationship (Smith, Hair, \& Ferguson, 2014). Market-oriented goals may be measured by company's market share and/or customer satisfaction. Financial performance is measured by profitability, return on investment, and return on sales (Chang, Ellinger, Kim, \& Franke, 2016).

\section{Customer Relationship (CR) and Firm Performance}

CR is described as the entire array of practices that are employed for the purpose of managing customer complaints, building long-term relationships with customer, and improving customer satisfaction (Li et al., 2006). Improving CR can enhance benefits by reducing coordination frictions and helping sellers learn about related buyer's utility (Shi, 2016). According to Bettencourt, Blocker, Houston, and Flint (2015), success in market place demands going beyond satisfactory exchanges with customers, therefore firms should build close relationship with their customers. A close customer relationship also allows an organization to differentiate its product from competitors, sustain customer loyalty, and dramatically extend the value it provides to its customers, therefore creating competitive advantage (Fathali, 2016). 


\section{Information Sharing (IS) and Firm Performance}

IS is usually considered in two aspects: quantity and quality. Companies share demand-related information with their upstream and downstream partners with the purpose of improving planning and coordination of logistics and production related activities (Cooper et al., 1997; Glenn Richey Jr, Chen, Upreti, Fawcett, \& Adams, 2009). Many researches in the field focused on the effect of information sharing on supply chain members' strategies and revenues (Huang \& Wang, 2017). The information sharing is profitable for both the supplier and manufacturer since with information shared suppliers would adjust the wholesale price and acquisition price to reach equilibrium between forward and reverse flows. It is expected that information sharing influences positively firm performance.

\section{Quality of Information Sharing (IQ) and Firm Performance}

Besides the level of information sharing, the quality of that information is also very important. The high level of information with low quality shared among partners in supply chain will limit the positive effect of general information sharing action. Marinagi, Trivellas, and Reklitis (2015) implied that information sharing among partners along the supply chain facilitates higher overall performance, as a result of enforced SCMPs elevating information reliability and quality. Efficient and friendly information technology applications may improve information sharing (Yang \& Maxwell, 2011). However, the main barriers and difficulties discouraging extend of information sharing are the cost and complexity of technological solutions, especially for SMEs (Brau, Fawcett, \& Morgan, 2007).

\section{Research Model, Hypotheses Development, and Measurement Scales}

\section{Research Model and Hypotheses}

Based on the preceding discussion of the relationship between firms' SCMPs and their performance, the following research model (see Figure 1) and hypotheses were proposed:

$\mathrm{H}_{1}$ : Supply chain management practices' constructs impact significantly on firm performance.

$\mathrm{H}_{2}$ : Supply chain management practices' constructs impact significantly on firm competitive advantages.

$\mathrm{H}_{3}$ : Firm competitive advantages impact significantly on firm performance.

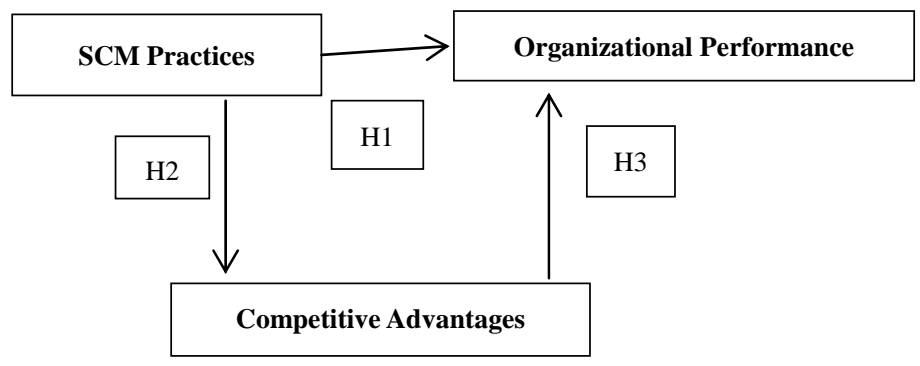

Figure 1. Research model.

\section{Measurement Scales}

Six latent variables are measured by 33 items. Table 2 shows all items utilized in this study. Altogether, 200 questionnaires were sent to SMEs located in Ho Chi Minh City, and 183 valid questionnaires were collected from 72 manufacturing firms, 57 trading firms and the rest from service providers. 
Table 2

Measurement Scale of Variables

\begin{tabular}{|c|c|c|}
\hline Variables & & Statement \\
\hline \multirow{4}{*}{$\begin{array}{l}\text { Strategic supplier partnership } \\
(S S P)\end{array}$} & SSP1 & We consider quality as our number one criterion in selecting suppliers. \\
\hline & SSP2 & We regularly solve problems jointly with our suppliers. \\
\hline & SSP3 & We have helped our suppliers to improve their product quality. \\
\hline & SSP4 & We have continuous improvement programs that include our key suppliers. \\
\hline \multirow{5}{*}{ Customer relationship $(C R)$} & CR1 & $\begin{array}{l}\text { We frequently interact with customers to set reliability, responsiveness, and other } \\
\text { standards for us. }\end{array}$ \\
\hline & CR2 & We frequently measure and evaluate customer satisfaction. \\
\hline & CR3 & We frequently determine future customer expectations. \\
\hline & CR4 & We facilitate customers’ ability to seek assistance from us. \\
\hline & CR5 & We periodically evaluate the importance of our relationship with our customers. \\
\hline \multirow{3}{*}{ Information sharing (IS) } & IS1 & Our trading partners share proprietary information with us. \\
\hline & IS2 & Our trading partners keep us fully informed about the issues that affect our business. \\
\hline & IS3 & Our trading partners share business knowledge of core business processes with us. \\
\hline \multirow{5}{*}{$\begin{array}{l}\text { Quality of information sharing } \\
(I Q)\end{array}$} & IQ1 & Information exchange between our trading partners and us is timely. \\
\hline & IQ2 & Information exchange between our trading partners and us is accurate. \\
\hline & IQ3 & Information exchange between our trading partners and us is complete. \\
\hline & IQ4 & Information exchange between our trading partners and us is adequate. \\
\hline & IQ5 & Information exchange between our trading partners and us is reliable. \\
\hline \multirow{10}{*}{ Competitive advantages $(C A)$} & CA1 & We are able to compete based on quality. \\
\hline & CA2 & We offer products that are highly reliable. \\
\hline & CA3 & We offer products that are very durable. \\
\hline & CA4 & We offer high quality products to our customers. \\
\hline & CA5 & We deliver the kind of products needed. \\
\hline & CA6 & We deliver customer order on time. \\
\hline & CA7 & We provide dependable delivery. \\
\hline & CA8 & We provide customized products. \\
\hline & CA9 & We alter our product offerings to meet client needs. \\
\hline & CA10 & We respond well to customer demand for "new" features. \\
\hline \multirow{6}{*}{ Firm performance $(F P)$} & FP1 & Market share \\
\hline & FP2 & Return on investment \\
\hline & FP3 & The growth of market share \\
\hline & FP4 & The growth of sales \\
\hline & FP5 & Growth in return on investment \\
\hline & FP6 & Profit margin on sales \\
\hline
\end{tabular}

\section{Reliability of Measurement Scales}

Reliability of measurement scale is measured by Cronbach's alpha value. Scale having Cronbach's alpha higher than 0.7 is reliable for studying. Varimax method and eigenvalues higher than 1 were used for factor analysis of 17 SCMP items resulted in four SCMPs' sub-constructs accounting for $66.71 \%$ of the total variance. Using the same method, the factor analysis of 10 competitive advantage items resulted in one construct accounting for $61.57 \%$ of the total variance. The factor analysis of six firm performance items resulted in one construct accounting for $77.28 \%$ of the total variance. Cronbach's alpha was used to test the reliability of the measurement as shown in Table 3. 
Table 3

Reliability Test for Latent Variables

\begin{tabular}{|c|c|c|c|c|c|}
\hline Items & $\begin{array}{l}\text { Scale mean if } \\
\text { item deleted }\end{array}$ & $\begin{array}{l}\text { Scale variance if } \\
\text { item deleted }\end{array}$ & $\begin{array}{l}\text { Corrected item - Total } \\
\text { correlation }\end{array}$ & $\begin{array}{l}\text { Cronbach's alpha if } \\
\text { item deleted }\end{array}$ & Cronbach’s alpha \\
\hline \multicolumn{6}{|c|}{ Strategic supplier partnership ( $S S P$ ) } \\
\hline SSP1 & 14.923 & 12.642 & 0.467 & 0.713 & \multirow{4}{*}{0.736} \\
\hline SSP2 & 15.202 & 12.316 & 0.557 & 0.659 & \\
\hline SSP3 & 15.399 & 12.472 & 0.587 & 0.645 & \\
\hline SSP4 & 15.377 & 12.368 & 0.507 & 0.689 & \\
\hline \multicolumn{6}{|c|}{ Customer relationship $(C R)$} \\
\hline CR1 & 21.104 & 27.138 & 0.688 & 0.869 & \multirow{5}{*}{0.885} \\
\hline CR2 & 21.475 & 25.141 & 0.728 & 0.860 & \\
\hline CR3 & 21.388 & 25.349 & 0.771 & 0.850 & \\
\hline CR4 & 21.475 & 25.855 & 0.739 & 0.857 & \\
\hline CR5 & 21.661 & 25.324 & 0.696 & 0.868 & \\
\hline \multicolumn{6}{|c|}{ Information sharing $(I S)$} \\
\hline IS1 & 8.661 & 7.654 & 0.600 & 0.658 & \multirow{3}{*}{0.757} \\
\hline IS2 & 8.027 & 8.708 & 0.610 & 0.658 & \\
\hline IS3 & 8.852 & 7.588 & 0.560 & 0.710 & \\
\hline \multicolumn{6}{|c|}{ Quality of information sharing $(I Q)$} \\
\hline IQ1 & 18.721 & 23.861 & 0.684 & 0.859 & \multirow{5}{*}{0.878} \\
\hline IQ2 & 18.995 & 22.346 & 0.792 & 0.832 & \\
\hline IQ3 & 19.077 & 22.917 & 0.739 & 0.845 & \\
\hline $\mathrm{IQ}^{*}{ }^{*}$ & 18.918 & 25.132 & 0.593 & 0.879 & \\
\hline IQ5 & 18.934 & 22.897 & 0.746 & 0.844 & \\
\hline \multicolumn{6}{|c|}{ Competitive advantages $(C A)$} \\
\hline $\mathrm{CA}^{*}$ & 49.459 & 88.205 & 0.684 & 0.923 & \multirow{10}{*}{0.928} \\
\hline $\mathrm{CA} 2^{*}$ & 49.403 & 85.575 & 0.793 & 0.917 & \\
\hline $\mathrm{CA}^{*}$ & 49.541 & 89.527 & 0.637 & 0.925 & \\
\hline CA4 & 49.547 & 86.616 & 0.753 & 0.919 & \\
\hline CA5 & 49.260 & 86.149 & 0.794 & 0.917 & \\
\hline CA6 & 49.586 & 84.411 & 0.736 & 0.920 & \\
\hline CA7 & 49.464 & 84.995 & 0.770 & 0.918 & \\
\hline CA8 & 49.453 & 83.483 & 0.837 & 0.914 & \\
\hline CA9 ${ }^{*}$ & 49.812 & 86.187 & 0.638 & 0.926 & \\
\hline CA10 ${ }^{*}$ & 49.923 & 87.894 & 0.598 & 0.928 & \\
\hline \multicolumn{6}{|c|}{ Firm performance $(F P)$} \\
\hline FP1 & 23.705 & 48.473 & 0.744 & 0.939 & \multirow{6}{*}{0.941} \\
\hline FP2 & 23.710 & 47.196 & 0.810 & 0.931 & \\
\hline FP3 & 23.732 & 45.867 & 0.877 & 0.922 & \\
\hline FP4 & 23.579 & 46.696 & 0.871 & 0.923 & \\
\hline FP5 & 23.732 & 47.065 & 0.850 & 0.926 & \\
\hline FP6 & 23.754 & 47.494 & 0.779 & 0.935 & \\
\hline
\end{tabular}

Note. Items marked by an asterisk were removed in the final measurement scales, and Cronbach's alpha recalculated to test the constructs' reliability as shown in Table 4. 
Table 4

Summary of Cronbach's Alpha

\begin{tabular}{lll}
\hline Constructs & Number of items & Cronbach's alpha \\
\hline Strategic supplier partnership $(S S P)$ & 4 & 0.736 \\
Customer relationship $(C R)$ & 5 & 0.885 \\
Information sharing $(I S)$ & 3 & 0.757 \\
Quality of information sharing $(I Q)$ & 4 & 0.879 \\
Competitive advantages $(C A)$ & 5 & 0.919 \\
Firm performance $(F P)$ & 6 & 0.941 \\
\hline
\end{tabular}

Statistic description shows the characteristics of probability distribution of six latent variables (see Table 5).

Table 5

Statistic Description

\begin{tabular}{lllllll}
\hline $\begin{array}{l}\text { Latent } \\
\text { variables }\end{array}$ & $\begin{array}{l}\text { Strategic } \\
\text { supplier } \\
\text { partnership }\end{array}$ & $\begin{array}{l}\text { Customer } \\
\text { relationship }\end{array}$ & $\begin{array}{l}\text { Information } \\
\text { sharing }\end{array}$ & $\begin{array}{l}\text { Quality of } \\
\text { information } \\
\text { sharing }\end{array}$ & $\begin{array}{l}\text { Competitive } \\
\text { advantages }\end{array}$ & Firm performance \\
\hline Mean & 5.075 & 5.355 & 4.257 & 4.730 & 5.566 & 4.740 \\
Median & 5.250 & 5.600 & 4.000 & 4.750 & 5.800 & 5.000 \\
Mode & 5.500 & 6.400 & 4.000 & 4.500 & 7.000 & 5.167 \\
Min. & 1.000 & 1.600 & 1.000 & 1.000 & 1.400 & 1.000 \\
Max. & 7.000 & 7.000 & 7.000 & 7.000 & 7.000 & 7.000 \\
STD & 1.128 & 1.251 & 1.334 & 1.251 & 1.170 & 1.365 \\
\hline
\end{tabular}

Correlation test was carried out before the hypothesis testing and the results are presented in Table 6 showing that all variables correlate significantly at the $1 \%$ level. All Pearson correlation coefficients are higher than 0.3 and lower than 0.8. Therefore, it is concluded that autocorrelation phenomenon does not exist.

Table 6

Correlation Matrix $(N=183)$

\begin{tabular}{lllllll}
\hline Variable & $F P$ & $C A$ & $S S P$ & $C R$ & $I S$ & $I Q$ \\
\hline$F P$ & 1 & & & & & \\
$C A$ & $0.553^{* *}$ & 1 & & & & \\
$S S P$ & $0.332^{* *}$ & $0.554^{* *}$ & 1 & & & \\
$C R$ & $0.508^{* *}$ & $0.706^{* *}$ & $0.596^{* *}$ & 1 & 1 & 1 \\
$I S$ & $0.419^{* *}$ & $0.300^{*}$ & $0.406^{* *}$ & $0.428^{* *}$ & $0.599^{* *}$ & 1 \\
$I Q$ & $0.486^{* *}$ & $0.461^{* *}$ & $0.410^{* *}$ & $0.453^{* *}$ & \\
\hline
\end{tabular}

Note. ${ }^{* *}$ : Correlation is significant at the 0.01 level (2-tail).

\section{Research Findings}

To test $\mathrm{H}_{1}$ (SCMPs' constructs impact on firm performance), linear regression test was run and the results showed that customer relationship and quality of information sharing impact on firm performance significantly at $0.01 \%$ level with $\beta=0.392$ and 0.291 , respectively (see Table 7), while the other two constructs (strategic supplier partnership and information sharing) do not have a significant relationship with firm performance at $5 \%$ level. Besides, there is no existence of collinearity phenomenon (VIF $<2$ ). Therefore, hypothesis $\mathrm{H}_{1}$ is accepted partially. 
Table 7

The Result of Hypothesis Testing for $H_{1}$

\begin{tabular}{|c|c|c|c|c|c|c|c|}
\hline & \multicolumn{2}{|c|}{$\begin{array}{c}\text { Unstandardized } \\
\text { coefficients }\end{array}$} & \multirow{2}{*}{\multicolumn{2}{|c|}{$\begin{array}{l}\text { Standardized } \\
\text { coefficients } \\
\text { Beta }\end{array}$}} & \multirow{2}{*}{ Sig. } & \multicolumn{2}{|c|}{ Collinearity statistics } \\
\hline & $\mathrm{B}$ & Std. error & & & & Tolerance & VIF \\
\hline Constant & 0.983 & 0.436 & & 2.256 & 0.025 & & \\
\hline$S S P$ & -0.050 & 0.094 & -0.041 & -0.530 & 0.597 & 0.610 & 1.639 \\
\hline$C R$ & 0.392 & 0.086 & 0.359 & 4.538 & 0.000 & 0.583 & 1.716 \\
\hline$I S$ & 0.125 & 0.080 & 0.122 & 1.568 & 0.119 & 0.600 & 1.667 \\
\hline$I Q$ & 0.291 & 0.086 & 0.267 & 3.384 & 0.001 & 0.587 & 1.704 \\
\hline
\end{tabular}

Note. Dependent variable: Firm performance (FP); Adjusted $R$ square: 0.335; Durbin-Watson: 1.757.

To test $\mathrm{H}_{2}$ (SCMPs' constructs impact on competitive advantage), linear regression test was run and the results showed that strategic supplier partnership, customer relationship and quality of information sharing impact on firm performance significantly at $0.1 \%$ level with $\beta=0.202,0.518$, and 0.204 , respectively (see Table 8), while information sharing impacts on competitive advantage negatively and significantly at $5 \%$ level. There is no existence of collinearity phenomenon (VIF $<2$ ). The test results show that SCMPs impact on company's competitive advantages significantly, thus hypothesis $\mathrm{H}_{2}$ is accepted.

Table 8

The Result of Hypothesis Testing for $\mathrm{H}_{2}$

\begin{tabular}{|c|c|c|c|c|c|c|c|}
\hline & \multicolumn{2}{|c|}{$\begin{array}{c}\text { Unstandardized } \\
\text { coefficients }\end{array}$} & \multirow{2}{*}{\multicolumn{2}{|c|}{$\begin{array}{l}\text { Standardized } \\
\text { coefficients } \\
\text { Beta }\end{array}$}} & \multirow[t]{2}{*}{ Sig. } & \multicolumn{2}{|c|}{ Collinearity statistics } \\
\hline & $\mathrm{B}$ & Std. error & & & & Tolerance & VIF \\
\hline Constant & 1.351 & 0.309 & & 4.370 & 0.000 & & \\
\hline SSP & 0.202 & 0.066 & 0.195 & 3.045 & 0.003 & 0.610 & 1.639 \\
\hline$C R$ & 0.518 & 0.061 & 0.554 & 8.456 & 0.000 & 0.583 & 1.716 \\
\hline$I S$ & -0.129 & 0.057 & -0.147 & -2.280 & 0.024 & 0.600 & 1.667 \\
\hline$I Q$ & 0.204 & 0.061 & 0.218 & 3.343 & 0.001 & 0.587 & 1.704 \\
\hline
\end{tabular}

Note. Dependent variable: Competitive advantage ( $C A$ ); Adjusted $R$ square: 0.545; Durbin-Watson: 1.772.

To test $\mathrm{H}_{3}$ (competitive advantage impact on firm performance), linear regression test was run and the results showed that competitive advantage impacts on firm performance significantly at $0.001 \%$ level with $\beta=0.947$ (see Table 9), thus hypothesis $\mathrm{H}_{3}$ is accepted.

Table 9

The Result of Hypothesis Testing for $\mathrm{H}_{3}$

\begin{tabular}{|c|c|c|c|c|c|c|c|}
\hline & \multicolumn{2}{|c|}{$\begin{array}{c}\text { Unstandardized } \\
\text { coefficients }\end{array}$} & \multirow{2}{*}{$\begin{array}{l}\text { Standardized } \\
\text { coefficients } \\
\text { Beta }\end{array}$} & $t$ & \multirow{2}{*}{ Sig. } & \multicolumn{2}{|c|}{ Collinearity statistics } \\
\hline & $\mathrm{B}$ & Std. error & & & & Tolerance & VIF \\
\hline Constant & 0.086 & 0.351 & & 0.246 & 0.806 & & \\
\hline$C A$ & 0.947 & 0.069 & 0.712 & 13.634 & 0.000 & 1.000 & 1.000 \\
\hline
\end{tabular}

Note. Dependent variable: Firm performance (FP); Adjusted $R$ square: 0.504; Durbin-Watson: 1.886.

\section{Discussion}

The research findings showed that customer relationship (CR) and quality of information sharing (IQ) impact on firm performance at $0.01 \%$ significance level while the level of information sharing impacts on firm performance at $10 \%$ significance level, and strategic supplier partnership impacts on firm performance 
insignificantly. Moreover, we also found that customer relationship and level of quality information sharing influence firm competitive advantage at $0.01 \%$ significance level, while the strategic supplier partnership and level of information impact on firm competitive advantage at $5 \%$ significance level. Competitive advantages impact significantly positively on firm performance at significance level of $0.001 \%$.

\section{Conclusion}

This study is one of the first researches towards supply chain field with SMEs as respondents. Six latent variables (strategic supplier partnership, customer relationship, information sharing, level of information quality, competitive advantages, and firm performance) are measured by 33 items. Altogether, 183 valid questionnaires were collected from 200 questionnaires sent to SMEs located in Ho Chi Minh City, among them 72 from manufacturing firms, 57 from trading firms and the rest from service providers. Three hypotheses were developed. We proposed that SCMPs, firm competitive advantages and firm performance have a significant relationship. The study results show that the four constructs of SCMPs influence significantly and positively firm competitive advantages, the three constructs of SCMPs (customer relation, information sharing, and the quality of information sharing) impact positively significantly on firm performance, and competitive advantage has a strong impact on firm performance.

The findings imply that in order to increase firm competitive advantages, Vietnamese SMEs should manage customer relationship well, be willing to share information to their partners, and increase the level of information quality as well as built partnership with their suppliers and customers, and through the improvement of competitive advantage they may gain great performance.

Although the research brought about some valid findings, it has some limitations such as sample size and sampling technique. We used a purposive sampling method with relative small sample size (183) of Vietnamese SMEs located in Ho Chi Minh City; therefore the generalization of the research findings is limited. The further researches should diversify the location and take into account cultural factors because cultural factors may cause the differences of SCMPs among firms located in different geography. In order to increase the generalization of the research results, using random sampling technique is suggested as well.

\section{References}

Afande, F. O., Ratemo, B. M., \& Nyaribo, F. N. (2015). Adoption of supply chain management practices: Review of determining factors. Innovative Systems Design and Engineering, 6(5), 72-77.

Bettencourt, L. A., Blocker, C. P., Houston, M. B., \& Flint, D. J. (2015). Rethinking customer relationships. Business Horizons, 58(1), 99-108.

Brau, J. C., Fawcett, S. E., \& Morgan, L. (2007). An empirical analysis of the financial impact of supply chain management on small firms. The Journal of Entrepreneurial Finance, 12(1), 55-82.

Burgess, K., \& Singh, P. J. (2006). A proposed integrated framework for analysing supply chains. Supply Chain Management: An International Journal, 11(4), 337-344.

Chang, W., Ellinger, A. E., Kim, K. K., \& Franke, G. R. (2016). Supply chain integration and firm financial performance: A meta-analysis of positional advantage mediation and moderating factors. European Management Journal, 34(3), $282-295$.

Chen, I. J., \& Paulraj, A. (2004). Towards a theory of supply chain management: The constructs and measurements. Journal of Operations Management, 22(2), 119-150.

Chicksand, D. (2015). Partnerships: The role that power plays in shaping collaborative buyer-supplier exchanges. Industrial Marketing Management, 48, 121-139.

Cooper, M. C., Lambert, D. M., \& Pagh, J. D. (1997). Supply chain management: More than a new name for logistics. The International Journal of Logistics Management, 8(1), 1-14. 
Elgazzar, S. H., Tipi, N. S., Hubbard, N. J., \& Leach, D. Z. (2012). Linking supply chain processes’ performance to a company’s financial strategic objectives. European Journal of Operational Research, 223(1), 276-289.

Ellram, L. M., Tate, W. L., \& Billington, C. (2007). Services supply management: The next frontier for improved organizational performance. California Management Review, 49(4), 44-66.

Fathali, A. (2016). Examining the impact of competitive strategies on corporate innovation: An empirical study in automobile industry. International Journal of Asian Social Science, 6(2), 135-145.

Glenn Richey Jr, R., Chen, H., Upreti, R., Fawcett, S. E., \& Adams, F. G. (2009). The moderating role of barriers on the relationship between drivers to supply chain integration and firm performance. International Journal of Physical Distribution \& Logistics Management, 39(10), 826-840.

Houlihan, J. B. (1985). International supply chain management. International Journal of Physical Distribution \& Materials Management, 15(1), 22-38.

Huang, Y., \& Wang, Z. (2017). Closed-loop supply chain models with product take-back and hybrid remanufacturing under technology licensing. Journal of Cleaner Production, 142, 3917-3927.

Khang, T. S., Arumugam, V., Chong, A. Y., \& Chan, F. T. (2010). Relationship between supply chain management practices and organisation performance: A case study in the Malaysian service industry. International Journal of Modelling in Operations Management, 1(1), 84-106.

Kim, S. W. (2009). An investigation on the direct and indirect effect of supply chain integration on firm performance. International Journal of Production Economics, 119(2), 328-346.

Lambert, D. M., \& Cooper, M. C. (2000). Issues in supply chain management. Industrial Marketing Management, $29,65-83$.

Lenny Koh, S. C., Demirbag, M., Bayraktar, E., Tatoglu, E., \& Zaim, S. (2007). The impact of supply chain management practices on performance of SMEs. Industrial Management \& Data Systems, 107(1), 103-124.

Li, S., Ragu-Nathan, B., Ragu-Nathan, T. S., \& Rao, S. S. (2006). The impact of supply chain management practices on competitive advantage and organizational performance. Omega, 34(2), 107-124.

Li, S., Rao, S. S., Ragu-Nathan, T. S., \& Ragu-Nathan, B. (2005). Development and validation of a measurement instrument for studying supply chain management practices. Journal of Operations Management, 23(6), 618-641.

Lii, P., \& Kuo, F. I. (2016). Innovation-oriented supply chain integration for combined competitiveness and firm performance. International Journal of Production Economics, 174, 142-155.

Marinagi, C., Trivellas, P., \& Reklitis, P. (2015). Information quality and supply chain performance: The mediating role of information sharing. Procedia-Social and Behavioral Sciences, 175, 473-479.

Min, S., \& Mentzer, J. T. (2004). Developing and measuring supply chain management concepts. Journal of Business Logistics, 25(1), 63-99.

Russell, R. S., \& Taylor, B. W. (2009). Operations management: Creating value along the supply chain. John Wiley \& Sons.

Shi, S. (2016). Customer relationship and sales. Journal of Economic Theory, 166, 483-516.

Smith, D., Hair, J. F., \& Ferguson, K. (2014). An investigation of the effect of family influence on commitment-trust in retailer-vendor strategic partnerships. Journal of Family Business Strategy, 5(3), 252-263. doi: 10.1016/j.jfbs.2013.11.005

Söderberg, L., \& Bengtsson, L. (2010). Supply chain management maturity and performance in SMEs. Operations Management Research, 3(1-2), 90-97. doi: 10.1007/s12063-010-0030-6

Somuyiwa, A., Mcilt, M., \& Adebayo, T. I. (2012). Firm's competitiveness through supply chain responsiveness and supply chain management practices in Nigeria. British Journal of Arts and Social Sciences, 10(1), 42-52.

Tan, K. C. (2001). A framework of supply chain management literature. European Journal of Purchasing \& Supply Management, $7(1), 39-48$.

Yang, T. M., \& Maxwell, T. A. (2011). Information-sharing in public organizations: A literature review of interpersonal, intra-organizational and inter-organizational success factors. Government Information Quarterly, 28(2), 164-175.

Zailani, S., Jeyaraman, K., Vengadasan, G., \& Premkumar, R. (2012). Sustainable supply chain management (SSCM) in Malaysia: A survey. International Journal of Production Economics, 140(1), 330-340. 